\title{
Media Coverage of the Arctic National Wildlife Refuge Drilling Controversy
}

\author{
RACHEL E. GOLDEN KRONER \\ George Mason University
}

\begin{abstract}
Protected areas are often subject to legal changes that allow natural resource extraction to occur within their boundaries. Controversy over whether to drill within a 1.5-million-acre coastal plain region of the Arctic National Wildlife Refuge (ANWR), specifically, the 1002 region, has been ongoing since the late 1970s and has been covered extensively in the media. This study compared local and national coverage of the ANWR drilling controversy in terms of volume and focus-pro- or anti-drilling-of media coverage. A content analysis of 100 news articles in three U.S. national newspapers and two Alaskan local newspapers was conducted using a three-point scoring scale. Scores were compared at the local and national levels. The study found that overall media coverage tended to focus on reasons to oppose drilling; there was little difference in coverage between local and national sources. This research informs future analyses of environmental controversies, especially those related to the influence of the media on political decisions.
\end{abstract}

\section{Introduction}

Protected public lands in the United States serve not only as ecological reserves, but they also symbolize the commitment of our country to preserving nature. Yellowstone National Park's establishment marked the creation of the world's first protected area in 1872. There are now more than 22,000 protected areas in the United States, currently covering $12 \%$ of the nation's land and $28 \%$ of the marine areas of the U.S. exclusive economic zone (EEZ) (International Union for the Conservation of Nature \& United Nations Environment Programme, 2014). The EEZ is the marine area of 200 nautical miles from the coast of which United States 
has sovereignty over energy production and protected area designation. Although generally considered to be under permanent protection, public lands such as national parks and national wildlife refuges often face changes to their laws or management practices, which may impact valuable resources. One framework in the literature that describes these legal changes is the Protected Area Downgrading, Downsizing, and Degazettement, or PADDD (Mascia \& Pailler, 2011). This framework includes three categories of legal changes: downgrades (legal allowances of additional anthropogenic activities in protected areas), downsizes (legal reductions in protected area size), and degazettes (complete legal abolishment of protection of a protected area). The framework is useful for understanding the dynamics of legal changes that affect protected areas and include changes that are not accounted for in national ledgers. Data on PADDD show that the United States has one of the highest rates of PADDD in the world, with 261 documented enacted events and over 1,800 documented proposed events since 1900 (World Wildlife Fund, 2014). In addition, many of the PADDD events that have occurred in the United States have been directly driven by infrastructure development and extractive industries such as oil and gas drilling (World Wildlife Fund, 2014).

PADDD events are often discussed in the media; such presentation in the media may drive public opinion about conservation and preservation, or conversely, about natural resource extraction (Shanahan, McBeth, Hathaway, \& Arnell, 2008). Comparisons between local and national media coverage of controversial environmental issues have been conducted to explore differences between volume and focus of coverage, and whether coverage is pro-preservation or pro-development (Bendix \& Leibler, 1999; Miller \& Pollack, 2013). For example, a study of the controversial spotted owl debate in the U.S. Pacific Northwest showed that newspapers published in the region covered the issue more often than outlets further away (Bendix \& 
Leibler, 1999). The overall slant of media coverage around the country was toward the "pro-cut" argument; in other words, the media published articles in support of the logging of timber, which was pitted against the preservation of the spotted owl's habitat (Bendix \& Leibler, 1999). In addition, the researchers found that there was no relationship between the geographic location of the source (proximate to the Pacific Northwest forest area) and the major focus of the articles. These findings were surprising to the researchers because they expected that the overall national coverage would favor the side of "pro-owl," as this would fall in line with assumptions that the national media coverage tends to be more liberal (Watts, Domke, Shah, \& Fan, 1999).

In order to understand the context surrounding proposed legal changes that affect a public protected area, media coverage regarding proposed drilling in the Arctic National Wildlife Refuge (ANWR) is an ideal case study. Whether to drill for oil in ANWR has been controversial since it was first proposed in 1977; the issue has been covered widely in the media. The area was established in 1960 to preserve wildlife and recreational ecosystem services (Alaska National Interest Lands Conservation Act, 1980). It is the largest protected area in the United States, covering over 19 million acres of land and water. Government management is provided by the U.S. Fish and Wildlife Service (USFWS, 2015). The ANWR is an extremely remote area with a diversity of ecosystems, including coastal zones and tundra, and species including caribou, polar bears, seals, muskoxen, bears, and wolves (Sovacool, 2006). The biological and ecosystem diversity of ANWR provides both intrinsic and instrumental value. The existence of rare and endangered species including polar bears and the remote wilderness landscape is inherently valuable simply because it exists (Leopold, 1949). In addition, the biodiversity of ANWR provides a storehouse of genetic diversity, which promotes ecosystem resilience (Chapin et al., 2000). The ANWR also comprises an area known as the 1002 area, which is estimated to contain 
between 5.7 and 16 billion barrels of technically recoverable oil, depending on the source consulted. The U.S. Geological Survey (USGS) has set the estimate at 7 billion barrels (USGS, 2011), which is estimated to be worth as much as $\$ 770$ billion (Bennett, 2012).

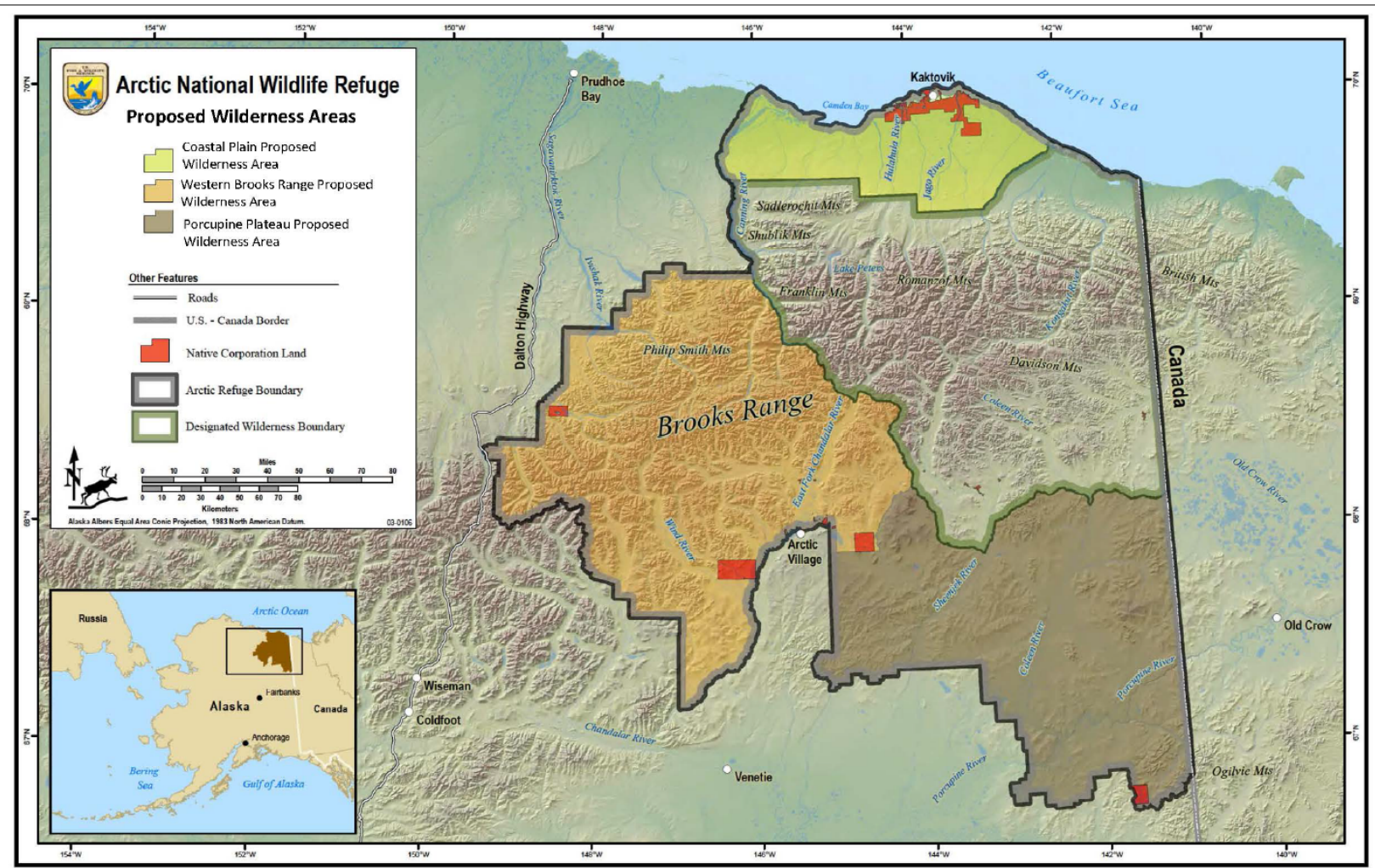

Figure 1. Location of the Arctic National Wildlife Refuge. From "Arctic National Wildlife Refuge Map," by the U.S. Fish and Wildlife Service, 2015. Retrieved from http://www.fws.gov/home/arctic-ccp/

The political controversy surrounding drilling for oil in the ANWR is of both national and local political importance. Not only is a national wildlife refuge managed by the federal government, but also its use directly affects local people and ecosystems. Proposals to drill in the 1002 area have been submitted to Congress since 1977, but none have been successful (Krauss, 2014). Each president since the late 1970s has provided an opinion on drilling in ANWR, usually falling along party lines with Democrats opposed and Republicans in support (Table 1). 
Table 1

Timeline of key events in and related to ANWR

\begin{tabular}{ll}
\hline Year & Key Event \\
\hline 1960 & Area designated wildlife range of 8.9 million acres. \\
1980 & $\begin{array}{l}\text { President Carter (D) signs bill more than doubling its size; Congress sets aside } \\
1.5 \text { million acres of coastal plain for possible oil exploration. }\end{array}$ \\
1989 & $\begin{array}{l}\text { Exxon Valdez oil spill raises public opposition that derails drilling legislation. } \\
1991\end{array}$ \\
& $\begin{array}{l}\text { Democrats block first President Bush's (R) plan to allow drilling in coastal } \\
\text { plain. }\end{array}$ \\
1995 & President Clinton (D) vetoes budget that includes drilling. \\
2001 & Second President Bush (R) proposes drilling; House approves it. \\
2002 & Senate blocks drilling in ANWR. \\
2003 & Senate proposes drilling in an Omnibus bill. \\
2005 & Drilling approved by the House, blocked in the Senate. \\
2008 & President Bush (R) urges Congress to remove ban on offshore drilling in \\
& ANWR. \\
& BP oil spill in the Gulf of Mexico.
\end{tabular}

Note. Adapted from Welch, W. (2002, April 18). Environmentalists, Democrats lead defeat of bill. USA Today. Retrieved from http://usatoday30.usatoday.com/news/nation/

2002/04/19/alaska-drilling-sidebar.htm

In addition to the national politics involved, local stakeholders have opposing views on this issue. For example, Alaskan residents receive economic benefits from drilling through the Alaska Permanent Fund. On average, each resident of Alaska received \$900 in 2013 (D’Oro, 2013) and \$1,884 in 2014 from oil revenues (Alaska Permanent Fund Corporation, 2014). In addition, two Alaska Native tribes live within the vicinity of the Refuge: the Inupiat and the Gwich'in (USFWS, 2012) and represent both sides of this controversy. Media sources suggest that the Inupiat tribe favors drilling in the region, likely due to their relationship with the oil industry (Welch, 2015). In particular, much of the economic development of Inupiat communities has been funded by revenues derived from drilling in Prudhoe Bay (Welch, 2015). In contrast, the Gwich'in tribe is portrayed by the media as anti-drilling because their traditional 
lifestyle depends on caribou, which in turn depend on ANWR for habitat (Wallace, 2005). All residents of Alaska, including tribal communities, along with local and national environmental and energy interests and politicians, have acted as key stakeholders in the political landscape (Moyer, 2008).

Local and national media have covered the issue extensively since the 1970 s, perhaps due to the diversity of stakeholders involved in the ANWR drilling controversy. The purpose of this study was to investigate and compare local and national coverage of the ANWR drilling controversy in terms of volume and focus-pro- or anti-drilling - of coverage. A content analysis was conducted using articles from local and national newspapers. Content analyses exist for other environmental issues, including issues related to water and agriculture (Altaweel \& Bone, 2012), ecosystem services (Lyytimäki, 2014), and the Florida panther (Jacobson, Langin, Carlton, \& Kaid, 2012). Content analyses are useful tools to monitor media coverage of controversial issues. The media is the conduit by which most people in the United States receive information about political and environmental issues (Happer \& Philo, 2013). Content analyses are also valuable tools to summarize and synthesize the available content related to any issue, environmental or otherwise, to which the public has access. This contrasts with a traditional academic literature review, focused on peer-reviewed journal articles to which the general public does not typically have access.

It was hypothesized that local media sources would cover the issue more often; however, local and national stances were expected to differ on this issue. In particular, local perspectives of drilling in ANWR as covered in Alaskan newspapers were hypothesized to be more supportive of drilling, as the economic benefits of drilling may directly benefit Alaskans. However, national perspectives on drilling were expected to be either more balanced or opposed 
to drilling, as they were expected to include perspectives from national or international environmental groups as well as politicians favoring environmental interests.

\section{Method}

In this study, a content analysis of major media outlets was conducted to examine oil and gas drilling proposals in the ANWR. The research focused on newspapers because of the longterm nature of the study; the newspaper as a medium has been used consistently since the 1970 s, unlike online sources. Research was conducted using the LexisNexis Academic database to search local and national newspapers. For full-text sources that were unavailable through LexisNexis, additional online databases of specific newspapers were used to query individual newspapers. To narrow the scope of media included, the top three daily national circulated newspapers according to the Alliance for Audited Media ${ }^{1}$ were examined: the Wall Street Journal, the New York Times, and USA Today. To compare national media coverage with local coverage, all Alaskan newspaper content that was generated in a LexisNexis search was included. The key word used to search LexisNexis was "Arctic National Wildlife Refuge" and the timeline was January 1, 1984 (the earliest record available in the database) to January 1, 2014. The search results for these criteria only included one Alaskan newspaper (Fairbanks Daily News Miner). To include an additional local Alaskan newspaper source in the analysis, the paper with the highest circulation in Alaska (Anchorage Daily News) was used. The same search terms and timeline were used for the Anchorage Daily News using the search function on the publication's archive page. Two Alaskan newspapers (instead of three) were used as these were the only sources available through LexisNexis or online archives. In total, the search yielded 1,165 articles.

${ }^{1}$ Additional information concerning the alliance can be found here: http://auditedmedia.com/ 
Using the articles generated from the search, the following questions were examined: How often is the ANWR drilling controversy covered in the media? What trends in media coverage are observed over time? How does media coverage of support or opposition to drilling in ANWR differ between media outlets (national versus local)?

After search criteria were applied to locate relevant articles, a subset of articles from each newspaper source was randomly selected as a sample for content analysis by selection every 10th article that appeared in the search results. Articles were selected from each source to review a sample from each. An attempt was made to include articles that spanned the thirty-year period from 1984 to 2014. Not all newspaper sources had the same number of articles; therefore, the selection of articles to review was not meant to be a representative sample of all news articles, but rather, a general sample of the content of each source. Selected articles were reviewed and scored on a 1 to 3 scale based on a scoring criteria which summarized the article's presentation of the pros and cons of drilling in ANWR (Table 2). With the scoring criteria in mind, each article was reviewed to determine whether the majority of the text of the article tended to focus on arguments to support or oppose drilling in ANWR. If the article was mostly supportive of drilling, it was assigned a score of 1 . If it was mostly opposed to drilling, it was given a score of 3. If the text was balanced between both opinions, the article was given a score of 2 .

For each article, the source name, date, and score were collected. Microsoft Excel was used to calculate descriptive statistics (mean, standard deviation) and to conduct an independent samples t-test using the mean scores for local and national sources. To analyze the content of the articles, qualitative information, especially the tone and phrases, were noted during the review. Using this qualitative review, a summary of the tone and phrasing was compiled to summarize patterns and trends. 
Table 2

Scoring criteria for news articles

\begin{tabular}{|c|c|c|c|}
\hline \multirow[t]{2}{*}{ Type of Coverage } & \multicolumn{3}{|c|}{ Scoring Criteria } \\
\hline & Description & Focus & Score \\
\hline $\begin{array}{l}\text { Mostly supportive } \\
\text { of drilling }\end{array}$ & $\begin{array}{l}\text { Majority of article text } \\
\text { focuses on support of } \\
\text { drilling in ANWR }\end{array}$ & $\begin{array}{l}\text { Likely to emphasize } \\
\text { economic assets as } \\
\text { more valuable than } \\
\text { environmental assets. }\end{array}$ & 1 \\
\hline Balanced & $\begin{array}{l}\text { Equal proportion of } \\
\text { article text devoted to } \\
\text { discussing each side of } \\
\text { the issue }\end{array}$ & & 2 \\
\hline $\begin{array}{l}\text { Mostly opposed to } \\
\text { drilling }\end{array}$ & $\begin{array}{l}\text { Majority of article text } \\
\text { focuses on opposition to } \\
\text { drilling in ANWR }\end{array}$ & $\begin{array}{l}\text { Likely to emphasize } \\
\text { environmental assets } \\
\text { as more valuable than } \\
\text { economic assets. }\end{array}$ & 3 \\
\hline
\end{tabular}

\section{Results}

\section{Volume of Coverage}

A total of 1,165 articles were generated in the search of two local and three national newspapers (Table 3). The Anchorage Daily News, an Alaskan paper, covered the topic most frequently, followed by the Wall Street Journal and the New York Times. There was little coverage in USA Today and the Fairbanks Daily News Miner. Samples from each newspaper were reviewed, for a total of 100 newspaper articles, which represents $8.5 \%$ of the total number of articles found $(\mathrm{n}=1165$; Table 3$)$. 
Table 3

Number of Articles Found and Reviewed

\begin{tabular}{llllll}
\hline Location & \multicolumn{5}{c}{ National } \\
\hline Source & Wall & New & USA & Anchorage & Fairbanks \\
& $\begin{array}{l}\text { Street } \\
\text { Journal }\end{array}$ & $\begin{array}{l}\text { York } \\
\text { Times }\end{array}$ & Today & $\begin{array}{l}\text { Daily } \\
\text { News }\end{array}$ & $\begin{array}{l}\text { Daily News } \\
\text { Miner }\end{array}$ \\
\cline { 2 - 6 } Found & $248^{2}$ & 243 & 12 & 652 & 10 \\
Reviewed & 29 & 24 & 12 & 25 & 10 \\
\hline
\end{tabular}

\section{Timeline of Coverage}

A timeline of the articles reviewed is presented in Figure 2. Spikes in coverage in this sample occurred in 1995 (12 articles), 2001 (12 articles), and 2005 (16 articles). The dates of articles available varied between sources (Table 4) as relevant articles were not found in each newspaper from the entire timeframe searched.

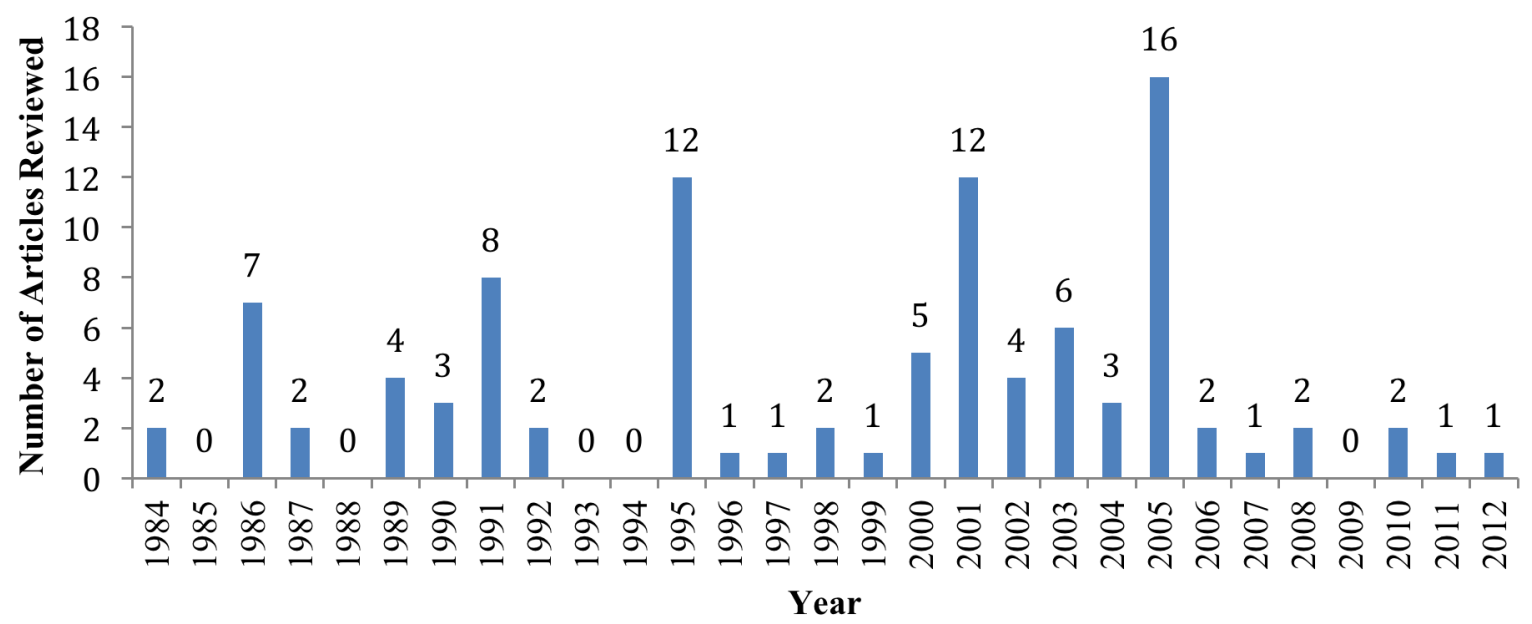

Figure 2. Timeline of articles reviewed, $1984-2012$

${ }^{2}$ Searched using ProQuest 


\section{Article Scores}

Overall, the coverage in the media of the articles sampled focused more on opposition to drilling and reasons for such opposition $(M=2.14, S D=0.84)$. Average and standard deviations of scores for national and local newspapers were compared (Table 4). The average score for local newspapers $(M=2.23, S D=0.85)$ was slightly higher than that of national newspapers $(M=$ $2.09, S D=0.85)$, indicating that the local articles were overall more opposed to drilling in the ANWR. However, differences in scores between local and national sources were not statistically significant, $t(70)=1.99, p>.05$.

The Fairbanks Daily News Miner stands out as having the highest score at 2.6 and the lowest standard deviation of any source at 0.70 . This is an indication that local, Alaskan news coverage tends to be more focused on opposition to drilling. However, this Alaskan newspaper had the lowest number of articles available and reviewed, so the small sample size could explain the disparity in scores between this source and others (Table 4).

Table 4

Comparison of Average Scores between the Five News Sources Reviewed

\begin{tabular}{llllll}
\hline Location & \multicolumn{3}{c}{ National } & \multicolumn{2}{c}{ Local } \\
\hline Source & $\begin{array}{l}\text { Wall } \\
\text { Street } \\
\text { Journal }\end{array}$ & $\begin{array}{l}\text { New } \\
\text { York } \\
\text { Times }\end{array}$ & $\begin{array}{l}\text { USA } \\
\text { Today }\end{array}$ & $\begin{array}{l}\text { Anchorage } \\
\text { Daily } \\
\text { News }\end{array}$ & $\begin{array}{l}\text { Fairbanks } \\
\text { Daily } \\
\text { News } \\
\end{array}$ \\
\cline { 2 - 6 } & & & & & Miner \\
Number of articles reviewed & 29 & 24 & 12 & 25 & 10 \\
Average score & 2.10 & 2.04 & 2.17 & 2.08 & 2.60 \\
Standard deviation of score & 0.90 & 0.81 & 0.83 & 0.86 & 0.70 \\
Range of dates reviewed & $1985-$ & $1989-$ & $1990-$ & $1986-$ & $2004-$ \\
& 2008 & 2012 & 2005 & 2011 & 2006 \\
\hline
\end{tabular}




\section{Content Analysis}

Despite their diversity, certain common patterns and trends emerged among the 100 media articles in terms of how issues on either side of the argument were discussed. For example, on the side of pro-drilling, arguments focused on the economic benefits of drilling, the provision of jobs, and the potential for the oil in ANWR to reduce the United States' dependence on foreign oil and contribute to the lowering of gas prices. Arguments in favor of drilling described ANWR as a barren wasteland, devoid of any other important source of revenue beyond that which could be provided by oil. Environmental impacts were highlighted as uncertain and avoidable given careful planning and improvements to technology and safety measures. The opinions of Inupiat people were also portrayed as being in favor of drilling, as they had previously benefitted from oil revenues.

In contrast, articles opposed to drilling focused on the environment, the risk of oil spills, and uncertainty about the amount and value of oil in ANWR. Environmental assets, especially wildlife and most especially the caribou, were discussed at length. Articles about the Exxon Valdez and BP oil spill controversies discussed the cost of oil spills, not only to the environment, but also to local people and the companies at fault. The wilderness of ANWR was described as unique and irreplaceable. Native people's opinions, especially of the Gwich'in tribe, were captured as opposing drilling; their traditional livelihoods depend on the hunting of caribou, which depends on ANWR for critical habitat. Opponents also expressed uncertainty about how much the additional oil supply would affect world oil prices and gas prices in the United States. 


\section{Discussion}

The results of this study demonstrated the following findings: 1) media coverage by local sources was high, 2) spikes in coverage corresponded with important events, and 3) local and national sources were about equally likely to oppose or support drilling.

\section{Volume of Coverage}

The highest volume of coverage was published in the Anchorage Daily News. This source is the most widely read newspaper in Alaska (Mondo Times, 2015). This result supported the original hypothesis that coverage would be higher in local sources. It also supports findings published by Bendix and Leibler (1999), whose focus on the spotted owl controversy demonstrated that local economic interests in timber and forests translated into higher media coverage of the issue in the Pacific Northwest region's newspapers. It is possible that local coverage was higher due to strong local economic interests in drilling, as well as heightened local concern over environmental impacts; more research is needed to confirm this explanation.

\section{Timeline of Coverage}

Several spikes in the timeline of coverage found in this study correspond with important events in the ANWR drilling controversy (Table 1). For example, the spike in 1995 occurred at the same time as a proposal to drill in the ANWR that was eventually vetoed by President Clinton (Welch, 2002). Two additional spikes in 2001 and 2005 occurred at the same time as other proposals blocked by the Senate (Welch, 2002). However, the timeline derived from the sample of articles reviewed did not capture every proposal and event related to drilling for oil in the ANWR (Table 1). It is possible that this result is a relic of the small sample size or the fact that other proposals to drill were less significant. An increase of the sample size to 20 or 30 percent of the articles available may capture each notable drilling proposal and event in the history of this controversy. 


\section{Article Scores}

The results of this content analysis did not support the hypothesis that local newspapers would be more "pro-drilling" than national sources due to the potential revenue Alaskans could receive from the Alaska Permanent Fund. However, local sources had slightly higher scores than national sources on average. Although many local Alaska articles focused on the economic benefits of drilling, more emphasized the value of wildlife, wilderness, and the rights of Alaska Native people who depend on caribou for traditional practices. However, the difference in scores between local and national sources was not statistically significant. This suggests that there was no meaningful difference in the focus of articles between the groups.

\section{Content Analysis}

The content analysis revealed that politics, emotions, and values drove both sides of the argument as evidenced by the allusions to political events and the emotive language used. . All sources utilized letters to the editor, editorials, and also long-form informational pieces to highlight opinions on this issue. The length and type of language varied. Articles included short, informative pieces about the proposal or passage of a bill through a chamber in Congress, editorials from prominent figures including President Jimmy Carter, and longer, balanced pieces emphasizing both sides of the issue.

\section{Limitations}

This study was limited by several factors, especially the sample size. The number of articles and newspaper sources could be increased in future studies. In addition, the scoring methods could be expanded to quantify the particular types of arguments made in each newspaper article. For example, articles could be coded according to their coverage of oil spills, Alaska Native interests, and the price of oil on the world market. More sources could be included to allow for a test of geographical correlation between the volume and score of coverage 
compared to the proximity to ANWR. It would be especially interesting to focus solely on Alaskan news sources (there are nine daily newspapers in Alaska) to gauge the variety of opinions printed there and compare them across the state according to proximity to the 1002 area. This, however, may prove difficult as many of the Alaskan news sources are not archived online.

\section{Implications}

This content analysis has implications for the communication of proposed PADDD events. As coverage of the ANWR drilling controversy has been so extensive, it serves as an ideal case study due to the volume of articles available for comparison and analysis. It appears that few other proposed PADDD events have received this much attention in the media; several exceptions exist including the recent proposals to drill in Virunga National Park in the Democratic Republic of Congo (Hogg, 2011) as well as the alteration of rules related to the use of snowmobiles in Yellowstone National Park (Eilperin, 2013). These PADDD events all occurred in large and well-established national parks. However, less media attention is paid to PADDD events in smaller and lesser known parks, even if their potential impacts could be significant. Environmental groups play a role in raising the profile of these events to the attention of the national media; advocacy contributes to the media's interest, thereby driving the content consumed by the public. It is possible that the media coverage of the ANWR drilling controversy was extensive due to the intrinsically emotional and symbolic nature of the issue, which involves oil extraction, wildlife, wilderness, native peoples, and risk of oil spills. Few political and PADDD events appear to involve such a rich interplay of opinions, values, and emotions, but this interplay has not been studied comprehensively across PADDD events. Future research should attempt to capture the factors involved. 
The analysis also has implications for the communication of science. The emphasis or deemphasis of scientific uncertainty was found on both sides of the argument. Uncertainty about the amount of oil was highlighted on the anti-drilling side and the uncertainty of the impacts on wildlife populations and the fragility of the ecosystem were highlighted on the pro-drilling side.

\section{Conclusion}

Overall, this review of media coverage provides new insight into one of the most controversial environmental issues in United States history: drilling in the Arctic National Wildlife Refuge. Findings showed that overall media coverage focused more on reasons to oppose drilling and that there was little difference in the media slant between local and national sources. Content analysis of this issue and other environmental issues should continue to be conducted with consistency to monitor public and political perceptions of these vital issues. This analysis and others like it may inform future studies on environmental controversies and public lands, especially related to the influence of the media on political decisions. 


\section{References}

Alaska National Interest Lands Conservation Act of 1980, Pub. L. No. 96-487, 94 Stat. 2390.

Alaska Permanent Fund Corporation. (n.d.). Annual dividend payouts. Retrieved from http://www.apfc.org/home/Content/dividend/dividendamounts.cfm

Altaweel, M., \& Bone, C. (2012). Applying content analysis for investigating the reporting of water issues. Computers, Environment and Urban Systems, 36, 599-613. http://dx.doi.org/10.1016/j.compenvurbsys.2012.03.004

Bendix, J., \& Liebler, C. M. (1999). Place, distance, and environmental news: Geographic variation in newspaper coverage of the spotted owl conflict. Annals of the Association of American Geographers, 89, 658-676. http://dx.doi.org/10.1111/0004-5608.00166

Bennett, M. (2012). After years of waiting, Shell Oil drill ships poised to explore Arctic Alaska. Alaska Dispatch. Retrieved from http://www.adn.com/article/after-years-waiting-shelloil-drillships-poised-explore-arctic-alaska

Chapin, F. S., Zavaleta, E. S., Eviner, V. T., Naylor, R. L., Vitousek, P. M., Reynolds, H. L., ... Díaz, S. (2000). Consequences of changing biodiversity. Nature, 405, 234-242. http://dx.doi.org/10.1038/35012241

D’Oro, R. (2013, September 18). Alaska dividend: Oil revenue means $\$ 900$ for each resident. Christian Science Monitor. Retrieved from http://www.csmonitor.com/Environment /Latest-News-Wires/2013/0918/Alaska-dividend-Oil-revenue-means-900-for-eachresident

Eilperin, J. (2013, February 22). Park service strikes compromise on snowmobiles in Yellowstone. The Washington Post. Retrieved from http://www.washingtonpost.com /national/health-science/park-service-strikes-compromise-on-snowmobiles-inyellowstone/2013/02/22/d5c9a81a-7d05-11e2-82e8-61a46c2cde3d_story.html

Happer, C., \& Philo, G. (2013). The role of the media in the construction of public belief and social change. Journal of Social and Political Psychology, 1, 321-336. http://dx.doi.org/10.5964/jspp.v1i1.96

Hogg, J. (2011, March 17). Congo confirms Virunga park oil ban, thwarts Soco. UK Reuters. Retrieved from http://uk.reuters.com/article/2011/03/17/congo-democratic-socoidUKLDE72G25E20110317

International Union for the Conservation of Nature, \& United Nations Environment Programme. (2014). The world database on protected areas (WDPA). Retrieved from http://www.protectedplanet.net

Jacobson, S. K., Langin, C., Carlton, J. S., \& Kaid, L. L. (2012). Content analysis of newspaper coverage of the Florida panther. Conservation Biology, 26, 171-179.

http://dx.doi.org/10.1111/j.1523-1739.2011.01750.x 
Krauss, C. (2014, August 28). Shell submits a plan for new exploration of Alaskan Arctic oil. New York Times. Retrieved from http://www.nytimes.com/2014/08/29/business/shellsubmits-a-plan-for-new-alaskan-arctic-oil-exploration.html

Leopold, A. (1949). A Sand County almanac. New York, NY: Oxford University Press.

Lyytimäki, J. (2014). Bad nature: Newspaper representations of ecosystem disservices. Urban Forestry and Urban Greening, 13, 418-424. http://dx.doi.org/10.1016/j.ufug.2014.04.005

Mascia, M. B., \& Pailler, S. (2011). Protected area downgrading, downsizing, and degazettement (PADDD) and its conservation implications. Conservation Letters, 4, 9-20. http://dx.doi.org/10.1111/j.1755-263X.2010.00147.x

Miller, T. \& Pollak, T. (2013). Environmental coverage in the mainstream news: We need more. Retrieved from http://environmentalcoverage.org/ranking/

Mondo Times. (2015). Highest circulation Alaska newspapers. Retrieved from http:/www.mondotimes.com/newspapers/usa/alaska-newspaper-circulation.html

Moyer, J. R. (2008). The ANWR landscape: A geographical analysis of rhetoric and representation (Master's thesis). Retrieved from http://cedar.wwu.edu/wwuet/15

Shanahan, E. A., McBeth, M. K., Hathaway, P. L., \& Arnell, R. J. (2008). Conduit or contributor? The role of media in policy change theory. Policy Sciences, 41, 115-138. http://dx.doi.org/10.1007/s11077-008-9058-y

Sovacool, B. K. (2006). Eroding wilderness: The ecological, legal, political, and social consequences of oil and natural gas development in the Arctic National Wildlife Refuge (ANWR). Energy and Environment, 17, 549-567. http://dx.doi.org/10.1260/095830506778644224

U.S. Fish and Wildlife Service (USFWS). (2012). Arctic: Refuge features. Retrieved from http://www.fws.gov/refuge/arctic/refuge_features.html

U.S. Fish and Wildlife Service (USFWS). (2015). Arctic. Retrieved from http://www.fws.gov /refuge/arctic/

U.S. Geological Survey. (2011). An evaluation of the science needs to inform decisions on outer continental shelf energy development in the Chukchi and Beaufort Seas, Alaska (Circular 1370). Retrieved from http://pubs.usgs.gov/fs/2011/3048/pdf/fs20113048.pdf

Wallace, S. (2005). ANWR: The great divide. Smithsonian, 36(7), 48. Retrieved from http://www.smithsonianmag.com/science-nature/anwr-the-great-divide-69848411/?no-ist

Watts, M. D., Domke, D., Shah, D. V., \& Fan, D. P. (1999). Elite cues and media bias in presidential campaigns explaining public perceptions of a liberal press. Communication Research, 26, 144-175. http://dx.doi.org/10.1177/009365099026002003 
Welch, C. (2015, May 15). Why Alaska's Inupiat are warming to offshore oil drilling. National Geographic. Retrieved from http://news.nationalgeographic.com/2015/05 /150522-Inupiat-Shell-offshore-oil-Arctic-Alaska-ocean-whale-sea/

Welch, W. (2002, April 18). Environmentalists, Democrats lead defeat of bill. USA Today. Retrieved from http:/usatoday30.usatoday.com/news/nation/2002/04/19/alaska-drillingsidebar.htm

World Wildlife Fund. (2014). PADDDtracker: Tracking protected area downgrading, downsizing, and degazettement [Beta version]. Retrieved from www.padddtracker.org 